\title{
WAWASAN NUSANTARA DALAM MEMCAHKAN KONFLIK KEBUDAYAAN NASIONAL
}

\author{
Hannah Annisa, Fatma Ulfatun Najicha \\ Universitas Sebelas Maret J1. Ir. Sutami No.36 Surakarta \\ email: hannah12@student.ac.id, fatmanajicha_law@staff.uns.ac.id
}

\begin{abstract}
ABSTRAK
Konflik antar budaya di Indonesia saat ini masih menjadi problematika yang belum terselesaikan. Indonesia sebagai negara kepualauan melahirkan keragaman ras, suku, dan budaya yang melandasi konsep kebudayaan nasional. Potensi akan konflik kebudayaan tidak dapat kita hindari. Pada dasarnya keterkaitan antara Geopolitik Indonesia, wawasan nusantara, dan kebudayaan nasional sangat erat, akan tetapi masyarakat Indonesia masih belum menyadari hal tersbut. Melalui studi literatur kita mempelajari kembali konsep dasar kewarganegaraan sehingga di dalam kehidupan nyata dapat kita implementasikan sebagai solusi dari adanya fenomena konflik antar budaya di Indonesia. Konflik antar budaya yang terjadi di Indonesia disebabkan oleh banyak hal seiring perubahan zaman, namun apabila kita cermati maka faktor utama dari konflik budaya tersebut adalah rendahnya kesadaran masyarakat sebagai bagian dari kesatuan Bangsa Indonesia untuk mewujudkan cita-cita dan mempertahankan keutuhan Negara Indonesia. Dari hasil studi literatur dapat disimpulkan bahwa suatu bangsa dalam menyelengarakan kehidupannya tidak terlepas dari pengaruh lingkungannya, yang didasarkan atas hubungan yang saling berkaitan antara filosofi bangsa, idiologi, aspirasi, dan cita-cita yang dihadapkan pada kondisi sosial masyarakat, budaya dan tradisi, keadaan alam dan wilayah serta pengalaman sejarah.
\end{abstract}

Kata Kunci: geopolitik indonesia, wawasan nusantara, konflik, kebudayaan nasional

\section{ABSTRACT}

Conflict between cultures in Indonesia is currently still a problem which has not been resolved. Indonesia as an archipelagic country gave birth to racial, ethnic and cultural diversity which underlies the concept of national culture. We cannot avoid the potential for cultural conflict. Basically, the relationship between Indonesian geopolitics, the archipelagic outlook, and national culture is very close, but the Indonesian people are still not aware of this. Through literature studies, we review the basic concept of citizenship so that in real life we can implement it as a solution to the phenomenon of intercultural conflict in Indonesia. The intercultural conflicts that occur in Indonesia are caused by many things as the times change, but if we look closely, the main factor of these cultural conflicts is the low awareness of society as part of the unity of the Indonesian nation to realize ideals and maintain the integrity of the Indonesian State. From the results of the literature study it can be concluded that a nation in carrying out its life is inseparable from the influence of its environment, which is based on the interrelated relationship between the nation's philosophy, ideology, aspirations, and ideals that are faced with the social conditions of society, culture and traditions, natural conditions. and territories and historical experiences.

Keywords: indonesian geopolitics, archipelagic outlook, conflict, national culture 


\section{PENDAHULUAN}

Indonesia menganut paham negara kepulauan berdasarkan Archipelago Concept yaitu laut sebagai penghubung daratan sehingga wilayah negara menjadi satu kesatuan yang utuh sebagai Tanah Air dan ini disebut negara kepulauan (Pasaribu, 2015). Ditinjau dari fenomena geografi Indonesia maka hal tersebut mengakibatkan kondisi masyarakat dengan multi budaya. Dalam kehidupan berbangsa dan bernegara keanekaragaman (pendapat, kepercayaan, hubungan, dsb) memerlukan suatu perekat agar bangsa yang bersangkutan dapat bersatu guna memelihara keutuhan negaranya. Upaya pemerintah dan rakyat menyelenggarakan kehidupannya, memerlukan suatu konsepsi berupa Wawasan Nasional yang dimaksudkan untuk menjamin kelangsungan hidup, keutuhan wilayah serta jati diri.

Sebagai sebuah negara dengan multi budaya, maka Indonesia memiliki potensi yang besar untuk terjadi konflik antar budaya dalam masyarakat. Konflik yang terjadi dalam kehidupan Bangsa Indonesia sebagaimana yang terlihat pada waktu belakangan ini di sejumlah daerah dapat digolongkan sebagai konflik yang mempunyai potensi mengancam dan membahayakan keutuhan hidup berbangsa dan bernegara. Konflik antar daerah, suku, agama, serta kelompok yang sekarang sering terjadi hanya akan memecah belah semangat persatuan dan kesatuan bangsa Indonesia.

\section{METODE PENELITIAN}

Pendekatan yang digunakan dalam penelitian ini adalah studi literatur terkait Geopolitik Indonesia, Wawasan Nusantara, Kebudayaan Nasional, dan Konflik Budaya. Dalam penelitian ini peneliti menggunakan studi literatur dimana peneliti mengambil sumber referensi yang mendukung penelitian ini. Teknik pengambilan data penelitian ini akan dilakukan dalam dua Langkah. Langkah pertama yaitu melakukan studi literatur pada buku, jurnal, dan artikel yang berhubungan dengan Geopolitik Indonesia, Wawasan Nusantara, Kebudayaan Nasional, dan Konflik Budaya. Langkah kedua yaitu dilakukan analisis data sekunder yang diperoleh. Terhadap data-data tersebut akan dikompilasi, dianalisis, dan disimpulkan sehingga diperoleh kesimpulan mengenai studi literatur.

\section{GEOPOLITIK INDONESIA}

Geopolitik secara etimologi berasal dari kata geo (bahasa Yunani) yang berarti bumi yang menjadi wilayah hidup. Sedangkan politik dari kata polis yang berarti kesatuan masyarakat yang berdiri sendiri atau negara; dan teia yang berarti urusan (politik) bermakna kepentingan umum warga negara suatu bangsa (Pasaribu, 2015). Sebagai acuan bersama, geopolitik dimaknai sebagai ilmu penyelenggaraan negara yang setiap kebijakannya dikaitkan dengan masalahmasalah geografi wilayah atau tempat tinggal suatu bangsa.

Istilah geopolitik semula oleh pencetusnya, Frederich Ratzel (1944-1904), diartikan sebagai ilmu bumi politik (Political Geography), Istilahn geopolitik dikembangkan dan diperluas lebih lanjut oleh Rudolf Kjellen (1864-1922) dan Karl Haushofer (1869-1946) menjadi Geographical Politic. Perbedaan kedua artian tersebut terletak pada fokus perhatiannya. Ilmu Bumi Politik (Political Geography) mempelajari fenomena geografi dari aspek politik, sedangkan geopolitik (Geographical Politic) mempelajari fenomena politik dari aspek geografi (Dwi Sulisworo, 2012).

Frederich Ratzel (1844-1904) berpendapat bahwa negara itu seperti organisme yang hidup. Negera identik dengan ruangan yang ditempati oleh sekelompok masyarakat (bangsa) pertumbuhan negara mirip dengan pertumbuhan organisme yang memerlukan ruang hidup (lebensraum) yang cukup agar dapat tumbuh dengan subur. Semakin luas ruang hidup maka negara akan semakin bertahan, kuat, dan maju. Oleh karena itu, jika negara ingin tetap hidup dan berkembang butuh ekspansi (perluasan wilayah sebagai ruang hidup).

Rudolf Kjellen (1964-1922) melanjutkan ajaran Ratzel, tentang teori organisme. Berbeda dengan Ratzel yang menyatakan negara seperti organisme, maka ia menyatakan dengan tegas bahwa negara 
adalah suatu organisme, bukan hanya mirip. Negara adalah satuan dan sistem politik yang menyeluruh yang meliputi bidang geopolitik, ekonomi politik, demo politik, sosial politik, dan krato politik. Negara sebagai organisme yang hidup dan intelektual harus mampu mempertahankan dan mengembangkan dirinya dengan melakukan ekspansi. Paham ekspansionisme dikembangkan. Batas negara bersifat sementara karena bisa diperluas. Strategi yang dilakukan adalah membangun kekuatan darat yang dilanjutkan kekuatan laut.

$$
\text { Karl Haushofer (1896-1946) }
$$

melanjutkan pandangan Ratzel dan Kjellen terutama pandangan tentang lebensraum dan paham ekspansionisme. Jika jumlah penduduk suatu wilayah negara semakin banyak sehingga tidak sebanding lagi dengan luas wilayah, maka negara tersebut harus berupaya memperluas wilayahnya sebagai ruang hidup (lebensraum) bagi warga negara. Untuk mencapai maksud tersebut, negara harus mengusahakan autarki, yaitu cita-cita untuk memenuhi kebutuhan sendiri tanpa bergantung pada negara lain. Hal ini dimungkinkan apabila wilayah negara cukup luas sehingga mampu memenuhi kebutuhan itu. Untuk itu politik ekspansi dijalankan. Berdasarkan asumsi demikian, Karl Haushofer membagi dunia menjadi beberapa wilayah (region) yang hanya dikuasai oleh bangsa-bangsa yang dikatakan unggul, seperti Amerika Serikat, Jerman, Rusia, Inggris, dan Jepang.

Istilah geopolitik untuk bangsa Indonesia dipopulerkan pertama kali oleh Ir. Soekarno. Pada pidatonya di hadapan sidang BPUPKI tanggal 1 Juni 1945. Berdasarkan pidato tersebut, berdasarkan geopolitik, wilayah Indonesia adalah satu kesatuan wilayah dari Sabang sampai Merauke, yang terletak antara dua samudera dan dua benua. Kesatuan antara bangsa Indonesia dengan wilayah tanah air itulah yang membentuk semangat dan wawasan kebangsaan, yaitu sebagai bangsa yang bersatu. Rasa kebangsaan Indonesia dibentuk oleh adanya kesatuan nasib, jiwa untuk bersatu dan kehendak untuk bersatu serta adanya kesatuan wilayah yang sebelumnya, bernama Nusantara.
Berbeda dengan teori yang dismpaikan oleh ilmuwan duania, Indonesia memiliki prinsip geolpolitik tersendiri. Prinsip geopolitik Indonesia menandakan bahwa dalam hal wilayah, bangsa Indonesia tidak ada semangat untuk mempeluas wilayah sebagai ruang hidup (lebensraum). Secara historis, kesepakatan para pendiri negara Republik Indonesia adalah wilayah Indonesia merdeka hanyalah wilayah bekas jajahan Belanda atau Hindia Belanda.

Ir. Soekarno dalam pidatonya menyebutkan bahwa syarat bangsa menurut Renan Ernest adalah "Le desir d'etre ensemble dan Character-gemeinschaft" yaitu suatu gerombolan manusia yang mau bersatu, yang merasa dirinya bersatu. Dengan kata lain sayarat bangsa adalah kehendak untuk Bersatu. Upaya membangun kesadaran untuk bersatunya bangsa dalam satu wilayah adalah dengan konsepsi Wawasan Nusantara.

\section{WAWASAN NUSANTARA}

Bangsa Indonesia memiliki pandangan sendiri mengenai wilayah yang dikaitkan dengan politik/kekuasaan. Wawasan Nusantara dapat dikatakan sebagai penerapan teori geopolitik dari bangsa Indonesia. Konsepsi Wawasan Nusantara dibentuk dan dijiwai oleh paham kekuasaan dan geopolitik bangsa Indonesia.

Bangsa Indonesia dalam menentukan wawasan nasional mengembangkan dari kondisi nyata. Indonesia dibentuk dan dijiwai oleh pemahaman kekuasan dari bangsa Indonesia yang terdiri dari latar belakang sosial budaya dan kesejarahan Indonesia. Untuk itu pembahasan latar belakang filosofi sebagai dasar pemikiran dan pembinaan nasional Indonesia ditinjau dari, (Pasaribu, 2015):

1. Pemikiran berdasarkan falsafah Pancasila.

Manusia Indonesia adalah makhluk ciptaan Tuhan yang mempunyai naluri, akhlak dan daya pikir, sadar akan keberadaannya yang serba terhubung dengan sesama, lingkungan, alam semesta dan dengan Penciptanya. Kesadaran ini menumbuhkan cipta, karsa dan karya 
untuk mempertahankan eksistensi dan kelangsungan hidupnya dari generasi ke generasi. Adanya kesadaran yang dipengaruhi oleh lingkungannya, manusia Indonesia memiliki motivasi demi terciptanya suasana damai dan tentram menuju kebahagiaan serta demi terselenggaranya keteraturan dalam membina hubungan antar sesamanya. Dengan demikian nilainilai Pancasila sesungguhnya telah bersemayam dan berkembang dalam hati sanubari dan kesadaran bangsa Indonesia, termasuk didalam menggali dan mengembangkan Wawasan Nasional. Wawasan Nasional merupakan pancaran dari Pancasila oleh karena itu menghendaki terciptanya persatuan dan kesatuan dengan tidak menghilangkan ciri, sifat dan karakter dari kebhinekaan unsurunsur pembentuk bangsa (suku bangsa, etnis dan golongan).

2. Pemikiran berdasarkan aspek kewilayahan.

Dalam kehidupan bernegara, geografi merupakan suatu fenomena yang mutlak diperhatikan dan diperhitungkan baik fungsi maupun pengaruhnya terhadap sikap dan tata laku negara. Wilayah Indonesia pada saat merdeka masih berdasarkan peraturan tentang wilayah teritorial yang dibuat oleh Belanda yaitu "Territoriale Zee en Maritieme Kringen Ordonantie 1939" (TZMKO 1939), dimana lebar laut wilayah/teritorial Indonesia adalah 3 mil diukur dari garis air rendah masing-masing pulau Indonesia.

3. Pemikiran berdasarkan aspek sosial Budaya. Budaya/kebudayaan secara etimologis adalah segala sesuatu yang dihasilkan oleh kekuatan budi manusia. Kebudayaan diungkapkan sebagai cita, rasa dan karsa (budi, perasaan, dan kehendak). Sosial budaya adalah faktor dinamik masyarakat yang terbentuk oleh keseluruhan pola tingkah laku lahir batin yang memungkinkan hubungan sosial diantara anggota-anggotanya.

4. Pemikiran berdasarkan aspek kesejarahan. Perjuangan suatu bangsa dalam meraih cita-cita pada umumnya tumbuh dan berkembang akibat latar belakang sejarah. Kerajaan Sriwijaya dan Majapahit landasannya adalah mewujudkan kesatuan wilayah, meskipun belum timbul rasa kebangsaan namun sudah timbul semangat bernegara. Kaidah-kaidah negara modern belum ada seperti rumusan falsafah negara, konsepsi cara pandang dsb. Yang ada berupa sloganslogan seperti yang ditulis oleh Mpu Tantular yaitu Bhineka Tunggal Ika. Penjajahan disamping menimbulkan penderitaan juga menumbuhkan semangat untuk merdeka yang merupakan awal semangat kebangsaan yang diwadahi Boedi Oetomo (1908) dan Sumpah Pemuda (1928) Wawasan Nasional Indonesia diwarnai oleh pengalaman sejarah yang menginginkan tidak terulangnya lagi perpecahan dalam lingkungan bangsa yang akan melemahkan perjuangan dalam mengisi kemerdekaan untuk mewujudkan cita-cita dan tujuan nasional sebagai hasil kesepakatan bersama agar bangsa Indonesia setara dengan bangsa lain.

Salah satu kepentingan nasional Indonesia adalah bagaimana menjadikan bangsa dan wilayah ini senantiasa satu dan utuh. Kepentingan nasional itu merupakan turunan lanjut dari cita-cita nasional, tujuan nasional maupun visi nasional. Cita-cita nasional bangsa Indonesia sebagaimana tertuang dalam pembukaan UUD 1945 alinea II adalah untuk mewujudkan Negara Indonesia, yang merdeka, bersatu, berdaulat, adil, dan makmur. Adapun tujuan nasional Indonesia sebagaimana tertuang dalam pembukaan UUD 1945 alinea IV, salah satunya adalah melindungi segenap bangsa Indonesia dan seluruh tumpah darah Indonesia. Visi nasional Indonesia menurut ketetapan MPR No.VII/MPR/2001 tentang Visi Indonesia 
Masa Depan adalah terwujudnya masyarakat Indonesia yang religius, manusiawi, bersatu, demokratis, adil, sejahtera, maju, mandiri, serta baik dan bersih dalam penyelenggaraan negara.

Dalam implementasi wawasan nusantara, masyarakat dihadapkan dengan tantangan. Tantangan tersebut berupa, (Dwi Sulisworo, 2012):

1. Pemberdayaan masyarakat dimana kondisi pembangunan nasional secara menyeluruh belum merata sehingga menimbulkan keterbelakangan, kemiskinan, dan kesenjangan sosial di masyarakat. Hal ini dapat merupakan ancaman bagi tetap tegak dan utuhnya NKRI.

2. Globalisasi Perkembangan IPTEK khususnya dibidang teknologi informasi, komunikasi, dan transportasi mempengaruhi pola piker bangsa Indonesia bahwa dunia menjadi transparan tanpa mengenal batas negara. Dalam tingkat kualitas sumber daya manusia di Indonesia yang masih terbatas, pemahaman tersebut merupakan ancaman bagi persatuan dan kesatuan.

3. Era baru kapitalisme diterapkan oleh negara-negara kapitalis dengan terus berusaha mempertahankan eksistensinya di bidang ekonomi dengan menekan negara-negara berkembang melalui isu global yang mencakup demokrasi, hak asasi manusia, dan lingkungan hidup demi kepentingan mereka. Hal ini dapat meruntuhkan sikap, pendirian dan kesadaran bangsa Indonesia terhadap nilai-nilai falsafah Pancasila dan rasa kebangsaan.

4. Rendahnya kesadaran warga negara tentang Hak dan Kewajiban. Manusia Indonesia mempunyai kedudukan, hak dan kewajiban yang sama. Hak dan kewajiban dapat dibedakan namun tidak dapat dipisahkan. Selain itu perlu adanya kesadaran bela negara dalam mengisi kemerdekaan perjuangan yang dilakukan melalui perjuangan non fisik untuk memerangi keterbelakangan, kemiskinan, kesenjangan sosial, memberantas $\mathrm{KKN}$, menguasai Iptek, meningkatkan kualitas SDM, transparan dan memelihara persatuan. dibandingkan pada perjuangan fisik.

Globalisasi sebagai tantangan dalam implementasi Wawasan Nusantara tidak hanya berdampak pada perkembangan IPTEK, namun juga pada bidang ekonomi. Globalisasi ekonomi merupakan manfestasi dari perkembangan kapitalisme sebagai sistem ekonomi internasional. Dampak dari globalisasi tersebut melunturkan kedaulatan sebuah negara. Kekuatan dari sebuah negara akan melemah seiring masuknya kebijakan institusi internasional seperti halnya Institusi WTO (World Trade Organization) dengan kebijakan pasar tebuka yang memaksa sebuah negara untuk tidak melindungi hak dasar warga negara atas lingkungan dan sumber daya alam. Berbagai regulasi diambil alih oleh sistem WTO bahkan merampas masyarakat dari kedudukan hukum danmengurangi regulasi atas perlindungan lingkungan. Sebagian dari pembangunan dan perdagangan bebas, pemerintah dengan perusahaan atau perusahaan nasional dengan perusahaan transnasional secara terus menerus mengeksploitasi sumber daya alam dan tidak melakukan pemeliharan likungan. Di sisi lain kedudukan hukum ekonomi berperan dalam pembangunan ekonomi dan manajemen sumber daya alam untuk mengadakan studi lanjut mengenai pembangunan ekonomi dan manajemen sumber daya alam yang menaungi khalayak banyak dengan tidak menciptakan hukum yang hanya mengedepankan kepentingan ekonomi pihak tertentu, namun juga mampu memberikan kemakmuran bagi masyarakat (Waluyo, 2019).

\section{KEBUDAYAAN NASIONAL}

Konsep bangsa (nation) merupakan konsep yang berada diantara konsep negara dan masyarakat. Konsep bangsa dibangun atas dasar rasa identitas komunal yang mempunyai sejarah tradisi yang relatif sama dan berelemen utama kebudayaan, yang mendiami unit geografi yang 
teridentifikasikan/disepakati bersama.

Berdasarkan konsep tersebut faktor

kebudayaan menjadi ciri suatu bangsa

dikarenakan sebuah kebudayaan akan

mencerminkan tingkat peradaban suatu bangsa.

Kebudayaan juga dapat dipahami sebagai suatu sistem ide/gagasan yang dimiliki suatu masyarakat lewat proses belajar dan dijadikan acuan tingkah laku dalam kehidupan sosial bagi masyarakat tersebut. Konsep kebudayaan Indonesia dibangun oleh para pendahulu kita. Konsep kebudayaan Indonesia disini mengacu kepada nilai-nilai yang dipahami, dianut, dan dijadikan pedoman bersama oleh bangsa Indonesia. Nilai-nilai inilah yang kemudian dianggap sebagai nilai luhur, sebagai acuan pembangunan Indonesia. Nilai-nilai itu antara lain adalah taqwa, iman, kebenaran, tertib, setia kawan, harmoni, rukun, disiplin, harga diri, tenggang rasa, ramah tamah, ikhtiar, kompetitif, kebersamaan, dan kreatif. Nilainilai itu ada dalam sistem budaya etnik yang ada di Indonesia. Nilai-nilai tersebut dianggap sebagai puncak-puncak kebudayaan daerah, sebagaimana sifat/ciri khas kebudayaan suatu bangsa Indonesia. Konsep kebudayaan Indonesia ini kemudian diikat dalam satu konsep persatuan dan kesatuan bangsa yaitu konsep Bhineka Tunggal Ika (Moeis, 2009). Oleh karena itu, tingkat peradaban Bangsa Indonesia dapat diukur dari seberapa tinggi toleransi masyarakat terhadap keanekaragaman budaya yang dimiliki oleh Bangsa Indonesia dalam kehidupan berbangsa dan bernegara.

Kebudayaan nasional itu merupakan "puncak-puncak dari kebudayaan daerah" sebagaimana apa yang dikatakan oleh $\mathrm{Ki}$ Hahar Dewantara. Politik Kebudayaan Nasioanl tidak hanya menyatakan dirinya dalam Kongres Kebudayaan tahun 1991, tnemun Kebudayaan Nasional secara tidak langsung "disebarluaskan" dan diwujudkan melalui penataran ideologi, yaitu penataran Pedoman Penghayatan dan Pengamalan Pancasila (P-4). Pancasila menjadi sumber dari semua nilai dan aturan (norma) dan ditempatkn pada kedudukan tolak ukur tunggal bagi nilai dan norma yang berlaku dan boleh dipedomi, sebagai arah dalam kehidupan berbangsa dan bernegara (Bangun, 1991).

MPR-RI melalui amandemen kedua UUD 1945, telah mengamanatkan dalam Pasal 18B ayat (2) bahwa: "Negara mengakui dan menghormati kesatuan-kesatuan masyarakat hukum adat beserta hakhak tradisionalnya sepanjang masih hidup dan sesuai dengan perkembangan masyarakat dan prinsip Negara Kesatuan Republik Indonesia, yang diatur dalam undang-undang”. Berdasarkan peraturan tersebut dapat kita ketahui bahwa undang-undang mengakui perbedaan sukubangsa yang besar di antara penduduk Indonesia dan menjamin persamaan status bagi semua sukubangsa yang ada tanpa melihat besarnya penduduk masing-masing suku bangsa. Semua suku bangsa memiliki hak yang sama untuk mengembangkann kebudayaan dan bahasa mereka masingmasing, membentuk pusat-pusat kebudayaan mereka sendiri, museum, dan lain-lain, namun bahasa yang digunakan dalam pendidikan resmi adalah bahasa Indonesia.

\section{KONFLIK BUDAYA}

Teori konflik melihat pertikaian dan konflik dalam sebuah sistem sosial. Masyarakat tidak akan selamanya berada dalam keteraturan dan akan selalu ada dominasi, koersi, dan kekuasaan dalam masyarakat. Otoritas yang berbeda-beda menghasilkan superordinasi dan subordinasi. Perbedaan antara superordinasi dan subordinasi dapat menimbulkan konflik karena adanya perbedaan kepentingan (Sumartono, 2019).

Kondisi geografis Indonesia memaksa masyarakatnya untuk tinggal menetap di daerah yang terpisah-pisah satu sama lain dan tersebar di berbagai titik. Mereka kemudian membentuk sebuah kelompok sosial yang didasari atas kesamaan lingkungan geografis dan hubungan timbal-balik secara intens. Masing-masing kelompok sosial memiliki ciri yang berbeda dikarenakan pola pikir, perilaku dan penyesuaian diri yang berbeda antara satu kelompok sosial dengan kelompok sosial yang lainnya. Hal tersebut menghasilkan sebuah identitas yang disepakati bersama dan dilestarikan di dalam sebuah kelompok sosial, 
sehingga tercipta suatu kebudayaan. Perbenturan budaya yang terjadi antar kelompok sosial itu lah yang disebut sebagai konflik kebudayaan.

Secara teori multi budaya merupakan potensi budaya yang dapat mencerminkan jati diri bangsa. Secara historis, multi budaya tersebut telah dapat menjadi salah satu unsur yang menentukan dalam pembentukan Negara Kesatuan Republik Indonesia. Selain itu, multi budaya juga menjadi modal budaya (cultural capital) dan kekuatan budaya (cultural power) yang menggerakkan dinamika kehidupan berbangsa dan bernegara. Namun di sisi lain multi budaya juga berpotensi untuk menimbulkan konflik yang dapat mengancam integrasi bangsa (Najwan, 2009).

Dari perspektif antropologi hukum, fenomena konflik dapat muncul, karena adanya konflik nilai, konflik norma dan/atau konflik kepentingan antar komunitas etnis, agama dan golongan dalam masyarakat. Selain itu, konflik yang terjadi juga dapat disebabkan sebagai akibat dari diskriminasi peraturan dan perlakuan pemerintah pusat terhadap masyarakat di daerah dengan mengabaikan, menghapuskan dan melemahkan nilai-nilai dan norma-norma hukum adat termasuk norma agama dan tradisi-tradisi masyarakat di daerah tersebut melalui dominasi dan pemberlakuan hukum negara (state law), (Najwan, 2009).

Beberapa faktor yang memungkinkan konflik etnis muncul ke permukaan menjadi konflik terbuka adalah (Harahap, 2018):

1. Perubahan konstelasi politik pada masa reformasi dan iklim kebebasan yang dijunjung tinggi menjadi peluang untuk mengungkapkan keresahan beberapa kelompok etnik.

2. Tidak meratanya pembangunan diberbagai wilayah di Indonesia, disadari atau tidak terpolarisasi berdasarkan kelompok etnik.

3. Tidak dapat dipungkiri bahwa dalam masyarakat Indonesia, identitas etnik menjadi faktor penting dalam kehidupan masyarakat, terutama perdesaan.
Penyebab konflik antar etnis dengan beberapa kasus konflik etnis yang pernah terjadi dan pemikiran yang berkembang dalam masyarakat adalah (Sumartono, 2019):

1. Dilema keamanan kelompok etnik. Segala usaha untuk meningkatkan keamanan yang dilakukan suatu kelompok sehingga menimbulkan reaksi balik dari kelompok lain dan apada akhirnya membuat

kelompok tersebut merasa kurang aman. Teori menjelaskan adanya otoritas

perang yang dapat terjadi jika suatu kelompok memiliki rasa tidak percaya pada kelompok etnis lain dan rasa tidak percaya ini berkembang menjadi mobilisasi kekuatan yang menegaskan kecurigaan antar kelompok yang juga menunjukkan maksud agresif, kondisi pemerintahan yang lemah, pemerintah pusat menjadi bagian dari konflik, situasi perubahan yang mendadak.

2. Perlindungan status. Kelompok berperang memepertahankan status sehingga

mucul ketakutan bahwa nilai-nilai dan cara hidup serta institusi kelompok etnis

tertentu bisa menjadi sub-ordinat kelompok etnis lain.

3. Ambisi hegemoni. Suatu kelompok yang berkuasa tidak cukup puas dengan bertahannya nilai-nilai budaya dan institusi mereka, tetapi ingin menjadi kelompok dominan yang menuntut perlakuan tertentu dari pemerintah.

4. Aspirasi kaum elit. Adanya ambisi dari elit kelompok etnik tertentu untuk mendapatkan dan mempertahanakan kekuasaan dengan menggunakan isuisu ketakukan, kebencian, dan ambisi kelompok etnik.

Konflik merupakan bagian dari dinamika sosial yang lumrah di setiap interaksi sosial dalam tatanan pergaulan keseharian masyarakat. Di dalam konflik selalu ada negosiasi-negosiasi yang dilakukan sehingga terciptalah suatu konsensus, oleh karena itu 
konflik dapat berperan sebagai pemicu proses menuju penciptaan keseimbangan sosial. Apabila konflik dapat dikelola dengan baik dapat juga dipakai sebagai perekat dalam kehidupan masyarakat. Konflik dalam masyarakat dapat membawa keadaan yang baik karena mendorong perubahan masyarakat, tetapi juga keadaan yang buruk apabila berkelanjutan tanpa mencari solusi yang dianggap bermanfaat bagi semua pihak (Sumartono, 2019).

\section{PEMBAHASAN}

Berbeda dengan konsep politik dunia yang dikemukakan oleh beberapa ahli di dunia, Indonesia memiliki konsep geopilitik sendiri yang dicetuskan oleh Ir. Soekarno. Para pendiri negara Republik Indonesia sepakat bahwa wilayah Indonesia merdeka hanyalah wilayah bekas jajahan Belanda atau Hindia Belanda. Oleh karena itu, Indonesia tidak ada keinginan untuk memperluas wilayah.

Ilmu geopolitik mempelajari fenomena geografi dari aspek politik. Indonesia memiliki kondisi geografis yang sangat kompleks, yaitu berupa negara kepulauan. Sehingga penduduknya tersebar di berbagai titik mendiami pulau-pulau yang dipisahkan oleh perairan Indonesia. Ilmu geopolitik mempelajari fenomena geografi tersebut dari sudut pandang politik. Di dalam ilmu politik, syarat sebuah bangsa adalah segerombolan manusia yang mau bersatu, yang merasa dirinya bersatu. Maka Indonesia membutuhkan suatu perekat untuk mewujudkan persatuan di antara masyarakatnya demi kelangsungan hidup bangsa.

Perekat tersebut diwujudkan dalam bentuk konsep cara pandang bangsa terhadap rakyat, bangsa, dan wilayah Negara Kesatuan Republik Indonesia yang meliputi darat, laut, dan udara di atasnya sebagai kesatuan politik, ekonomi, sosial, budaya, dan pertahanan keamanan. Hal itu tertuang dalam konsep Wawasan Nusantara. Pembentukan konsep Wawasan Nusantara dilatarbelakangi oleh pemikiran berdasarkan empat aspek, yaitu: (1) Falsafah pancasila, (2) Aspek kewilayahan, (3) Aspek sosial budaya, dan (4) Aspek kesejarahan.
Apabila ditinjau dari aspek sosial budaya, maka Indonesia merupakan negara dengan multi budaya, hal ini disebabkan oleh faktor geografis dan sejarah, namun keanekaragaman budaya tersebut menjadi bagian dari satu kesatuan budaya, yaitu kebudayaan nasional yang mengacu pada nilai-nilai luhur budaya Indonesia dalam rumusan Pancasila. Pancasila menjadi tolak ukur utama dalam pelaksanaan Kebudayaan Nasional, sehingga dalam mewujudkan persatuan keanekaragaman budaya yang ada di Indonesia distakuan melalui prinsip Bhineka Tunggal Ika.

Sesuai dengan sifatnya, kebudayaan merupakan warisan yang bersifat memaksa bagi masyarakat yang bersangkutan. Artinya setiap generasi yang lahir dari suatu masyarakat akan mewarisi norma-norma budaya dari generasi sebelumnya. Warisan budaya diterima secara emosional dan bersifat mengikat ke dalam (Cohesiveness) sehingga menjadi sangat sensitif. Berdasar ciri dan sifat kebudayaan serta kondisi dan konstelasi geografi, masyarakat Indonesia sangat heterogen dan unik sehingga mengandung potensi konflik yang sangat besar, terlebih kesadaran nasional masyarakat yang relative rendah sejalan dengan terbatasnya masyarakat terdidik. Besarnya potensi konflik antar golongan di masyarakat yang setiap saat akan membuka peluang terjadinya disintegrasi bangsa. Oleh karena itu, dalam menghadapi konflik budaya kita membutuhkan kesamaan persepsi atau kesatuan cara pandang diantara segenap masyarakat tentang eksistensi budaya yang sangat beragam, namun memiliki semangat untuk membina kehidupan bersama secara harmonis.

\section{KESIMPULAN}

Wawasan Nusantara tidak hanya sebuah konsep tentang cara pandang terhadap bangsanya sendiri, namun juga menyadarkan rakyat bahwa keanekaaragaman budaya di antara masyarakat Indonesia berada di dalam satu kebudayaan yang mengikat di dalam sebuah negara yang memiliki arah yang sama yaitu mewujudkan persatuan dan cita-cita bangsa sebagaimana termaktub dalam UUD 1945. Secara geografis menyebabkan 
penduduk Indonesia terpisah dan berkembang menyesuaikan lingkungannya membentuk sebuah kelompok sosial yang memiliki ciri khas masing-masing, namun hal itu bukan berarti suatu kelompok sosial yang memiliki kebudayaan tadi bertujuan untuk bersaing dan menguasai budaya lain sehingga menimbulkan konflik antar budaya. Rendahnya pemahaman dasar sebagai warga negara Indonesia menyebabkan etnosentrisme yang dapat mengancam integrasi bangsa. Oleh karena itu perlu untuk kita kembali mempelajari Wawasan Nusantara.

Perlu adanya pendidikan moral, pengembangan wawasan, ketrampilan serta penanaman rasa nasionalisme pada generasi muda, karena merekalah tulang punggung negara di masa yang akan datang. Salah satunya melalui penanaman nilai-nilai kepribadian bangsa Indonesia yang tercermin dalam Pancasila dan semboyan bangsa kita "Bhineka Tunggal Eka" kepada meeka sehingga mereka kelak ketika mereka menjadi pemimpin, bukan hanya sebagai Ulil Amri atau Umara tetapi juga bersifat Khadimul Ummah (pelayan umat) dalam segala bidang aspek kehidupan berbangsa dan bernegara tanpa melihat kaya miskin, pejabat atau rakyat, suku, ras, agama atau hal yang lain karena semua adalah sama dan tetap satu yaitu untuk Indonesia (Najicha, 2017).

\section{DAFTAR RUJUKAN}

Bangun, P. (1991). Kongres Kebudayaan 1991: Kebudayaan daerah dan Kebudayaan Nasional (Abstraksi). Jakarta: Direktorat Jenderal Kebudayaan Departemen Pendidikan dan Kebudayaan.

Dwi Sulisworo, T. W. (2012). Program Studi Kewarganegaraan Hibah Non Konvensional. Yogyakarta: Universitas Ahmad Dahlan.

Harahap, S. (2018). Konflik Etnis dan Agama di Indonesia. Jurnal Ilmiah Sosiologi Agama, No. 2, Vol. 1.

Moeis, D. S. (2009). Pembentukan Kebudayaan Nasional Indonesia. Jurusan Pendidikan Sejarah FPIPS
UPI Bandung. Bandung: Universitas Pendidikan Indonesia.

Najicha, F. U. (2017). Aku Generasi Unggul Masa Depan, Generasi Muda Harapan Bangsa. Esai Penerima Beasiswa Program Doktor Ilmu Hukum .

Najwan, J. (2009). Konflik Antar Budaya dan Antar Etnis di Indonesia Serta Alternatif Penyelesaiannya. Jurnal Hukum, No. Edisi Khusus, Vol. 16.

Pasaribu, R. B. (2015). Bab 7 Wawasan Nusatara. Dalam R. B. Pasaribu, Pendidikan Kewarganegaraan. Depok: Universitas Gunadarma.

Sumartono. (2019). Dinamika Perubahan Sosial Dalam Teori Konflik. Jurnal Ilmu Komunikasi dan Bisnis, No. 1, Vol. 5.

Waluyo, F. U. (2019). Law in the Globalization and Its Influence on Economic Development and Environmental Preservation based on Pancasila and the Indonesian Constitution of 1945. Advances in Social Science, Education and Humanities Research, volume 358. 